\title{
BIOLOGICAL AND ECONOMIC ASSESSMENT OF FATTENING EGYPTIAN NATIVE BULLOCKS IN A NEWLY RECLAIMED AREA
}

\author{
S. M. Alsheikh, A. A. Younis ${ }^{\text {Late }}$ and M. M. Mokhtar \\ Desert Research Center, Mataria, Cairo 11753, Egypt
}

\section{SUMMERY}

Data of 53 bullocks in summer and 201 bullocks in winter were collected from a commercial feedlot farm located in a newly reclaimed area, some $90 \mathrm{~km}$ from Cairo on the Cairo-Alexandria desert road during the agricultural year 1997-1998. The goal of the study was to evaluate the biological and economic performance of fattening enterprises of Egyptian native bullocks in both winter and summer seasons, In addition to introduce solution to help improve the return of LE per year. The average initial body weight was $280 \pm 4.207$ and $299 \pm 2.160 \mathrm{~kg}$ in summer and winter, respectively. The bullocks were individually fed mainly on concentrates (14\% crude protein) plus roughage offered ad libtum. The age of these bullocks ranged from 6 months to less than two years. Data were analyzed using the General Linear Models (GLM) procedure. Alternative feeding regime was suggested depending on replacement of $50 \%$ of the concentrates in winter by berseem (Trifolium alexantrinum) as a solution to improve the return per LE per year. The average daily gain was $1.17 \mathrm{~kg}$ and $1.11 \mathrm{~kg}$ in summer and winter, respectively. The corresponding values of feed conversion ( $\mathrm{kg}$ dry matter intake per $\mathrm{kg}$ body weight gain) were $9 \mathrm{~kg}$ and $10 \mathrm{~kg}$. The values of return per animal were LE 392 and LE 316 in summer and winter seasons, respectively. Feeding cost accounted for $86 \%$ and $87 \%$ of the total variable cost in summer and winter seasons, respectively. The return per LE per year was $12 \%$. The alternative feeding regime reduced the total feeding cost to $82 \%$ and improved the return per LE per year to $19 \%$. It could be concluded that, the economic analysis of this farm appeared that the intensification to obtain high biological performance was not enough to obtain the high value of the return per LE per year. So, to improve the value of the return per LE per year, other criteria could be taken into consideration such as reducing feeding cost using available green fodder.

Keywords: Cattle, Daily gain, farm income, return

\section{INTRODUCTION}

In Egypt, small holders own more than 90 percent of livestock. Actually, cattle and buffaloes produce about 80 percent of red meat (Abdel-Aziz, 1997). Hence, farms with small number of local cattle get rid of their calves soon after weaning or after the termination of the green fodder season. These small farms supply stock to feedlots for fattening in specialized farms. In most cases, middlemen collect these calves from local markets and sell them to fattening farms. Concentrates are

Issued by The Egyptian Society of Animal Production 
purchased from factory and/ or made on the farm from available local ingredients, which are usually cheap. Straw and hay are usually bought seasonally to avoid out of season high prices.

Large-scale feedlots for cattle follow landless production system (Sere and Steinfeld, 1996) and mainly depend on the transport of feeding stuffs from outside the farm. This system produces about $12 \%$ of the global production of beef and contributed about $20 \%$ of beef production in Egypt (Abdel-Aziz, 1997). It is also high capital, labor, and feed intensive. These feedlots are scattered in different parts of Egypt especially in newly reclaimed areas.

The key efficiency parameters in the feedlot farm are daily weight gain, feed conversion and economic return. However, up till now, the relative importance of the input items has not been precisely examined under practical Egyptian farm conditions.

Therefore, the aim of the present study was to evaluate the biological and economic performance of the enterprises of fattening Egyptian native bullocks under commercial conditions in both winter and summer seasons in a newly reclaimed area. In addition to introduce solution to help improve the return of LE per year.

\section{MATERIALS AND METHODS}

Data of 53 bullocks in summer and 201 bullocks in winter were collected from a commercial feedlot farm located in Wadi El-Natroon some $90 \mathrm{~km}$ Northwest of Cairo on the Cairo-Alexandria desert road. The average initial body weight was $280 \pm 4.207$ and $299 \pm 2.160 \mathrm{~kg}$ in summer and winter, respectively. Bullocks were bought from October to January (winter season) and from May to June (summer season) during the agricultural year 1997-1998. They were individually fed mainly on concentrates feed mix (14\% crude protein) purchased from outside the farm plus roughage (bean and wheat straw) offered ad libtum. The age of these bullocks was not estimated, while they ranged from 6 months to less than two year. They were vaccinated and drenched before fattening started. Fresh water was available to animals twice daily. Animals were housed in five barns; 50 bullocks each. Barns were made of bricks, with a ceiling $6 \mathrm{~m}$ high made of corrugated metal sheets, and well ventilated. Two laborers were in change of each barn serving 50 bullocks. Also, a manger and two specialists were managing the farm.

\section{Data analysis:}

Data were analyzed using the General Linear Models (GLM) procedure (SAS,1998). Tests of significance were done according to Duncan's Multiple Range Test (1955). These data were analyzed according to the following model:

where,

$$
\mathrm{Y}_{\mathrm{ij}}=\mu+\mathrm{S}_{\mathrm{i}}+\beta \mathrm{W}_{\mathrm{ij}}+\mathrm{e}_{\mathrm{ij}}
$$

$\mathrm{Y}_{\mathrm{ij}}=$ any $\mathrm{j}^{\text {th }}$ observation on $\mathrm{i}^{\text {th }}$ season,

$\mu \quad=$ overall mean,

$\mathrm{S}_{\mathrm{i}} \quad=$ effect of $\mathrm{i}^{\text {th }}$ season $\mathrm{i}=1-2$,

$\beta=$ regression coefficient of final weight on initial weight,

$\mathrm{W}_{\mathrm{ij}}=$ deviation of initial weight from its average,

$\mathrm{e}_{\mathrm{ij}}=$ random error. 
Alternative feeding regime:

Data collected from this farm showed that, all feeds offered in both summer and winter seasons, and no green fodder was provided. So, an alternative type of feeding regime, could be suggested which dependent on replacement of $50 \%$ of concentrates feeding in winter by berseem (Trifolium alexantrinum), which is available in winter season. In this case, The amount of berseem which covers $50 \%$ of nutritional requirements of the animal feeding to produce $1.2 \mathrm{~kg}$ daily gain was $15 \mathrm{~kg}$ per day (Crampton and Harris, 1996). The price of a $\mathrm{kg}$ berseem was LE 0.065 (farm gate prices in March 2003). The total feeding cost in the case of using berseem was modified according to the following equation:

$$
\mathrm{TFC}=\mathrm{CCFS}+(\mathrm{CHCFW}+(\mathrm{P} * \mathrm{M} * \mathrm{FP} * \mathrm{NFB})),
$$

where,

TFC = total feeding cost LE,

CCFS = cost of concentrates feeding in summer LE,

$\mathrm{CFCFW}=$ cost of $50 \%$ of concentrates feeding in winter LE,

$\mathrm{P} \quad=$ price of a $\mathrm{kg}$ berseem LE,

$\mathrm{M} \quad=$ Amount of barseem used $/ \mathrm{kg} / \mathrm{day}$,

$\mathrm{FP} \quad=$ fattening period in winter day,

NFB $=$ No. of fattening bullocks in winter head.

\section{RESULTS AND DISCUSSION}

\section{Biological performance:}

Season significantly affected final weight, average daily gain and fattening period but these effects being non significant when initial body weight was corrected $(p<0.05)$. This result was obtained due to that, the summer season had less initial body weight than that of winter, which allowed animals to attain higher final weight than those in winter season (Table1).

Averages dry matter intake (DMI)/ head/ day and efficiency of feed conversion (Kg DMI/ Kg body weight gain) represented in table 1. Indicating a slight depression in the feed intake and feed conversion of animals fattened during summer months. This could result from the negative effects of heat stress as reported by Younis and Mokhtar (1999). These result were within the range suggested by Sere and Steinfeld (1996) of 8 to $10 \mathrm{~kg}$ DMI per $\mathrm{kg}$ of live body weight gain as feed conversion rate for animals fattened under landless production system.

The average daily gain (Table 1) being higher than the previous estimates reported of $0.801 \mathrm{~kg}$ (Galal et al., 1973), $0.750 \mathrm{~kg}$ (Kamar et al., 1961) and $0.600 \mathrm{~kg}$ (Asker and Ragab, 1958). However, the present values were within the range obtained by El-Ashry et al. (1985) on different nutritional treatments of Brown Swiss male caves (from 0.830 to $1.160 \mathrm{~kg}$ ). Also, Sere and Steinfeld (1996) reported values close to those obtained in the present study $(1.0$ to $1.5 \mathrm{~kg})$. The present results demonstrated the ability of local cattle to put on weight once kept within the intensive production system. 
Table 1. Least squares means (LSM) \pm standard error (SE) for some biological parameters in different two fattening seasons

\begin{tabular}{|c|c|c|c|c|c|}
\hline \multirow{2}{*}{ Parameters } & \multicolumn{2}{|c|}{ Summer season } & \multicolumn{2}{|c|}{ Winter season } & \multirow{2}{*}{$\begin{array}{c}\text { Overall } \\
\text { Mean }\end{array}$} \\
\hline & LSM & $\pm \mathrm{SE}$ & LSM & $\pm \mathrm{SE}$ & \\
\hline Number (head) & \multicolumn{2}{|c|}{53} & \multicolumn{2}{|c|}{201} & 254 \\
\hline Final Weight (kg) & $445^{\mathrm{a}}$ & \pm 6.340 & $433^{\mathrm{a}}$ & \pm 2.485 & 439 \\
\hline Fattening period (day) & $120^{\mathrm{a}}$ & \pm 4.486 & $118^{\mathrm{a}}$ & \pm 1.759 & 119 \\
\hline Total gain (kg / head) & $141^{\mathrm{a}}$ & \pm 6.659 & $129^{\mathrm{a}}$ & \pm 2.611 & 135 \\
\hline Av. Daily gain (kg) & $1.17^{\mathrm{a}}$ & \pm 0.051 & $1.11^{\mathrm{a}}$ & \pm 0.020 & 1.14 \\
\hline Av. DMI* (kg / head / day) & $10^{\mathrm{a}}$ & \pm 1.645 & $11^{\mathrm{a}}$ & \pm 1.232 & 10.5 \\
\hline Biological efficiency** & $9^{\mathrm{a}}$ & \pm 2.233 & $10^{\mathrm{a}}$ & \pm 1.897 & 9.5 \\
\hline
\end{tabular}

Values were rounded to the nearest integer.

Means with the same superscript letter in the same row are not significantly different $(p<0.05)$.

* DMI = Dry matter intake. $\quad$ ** No. of $\mathrm{kg} \mathrm{DMI} / \mathrm{kg}$ body weight gain.

\section{Economic performance:}

Feeding cost represented the highest fraction of the total running cost in both seasons (Table 2). The cost values of animal feeding were LE 651 and LE 624 in summer and winter fattening, respectively (1 US dollar = LE 6.5).

However, the feeding cost per animal was higher in summer than in winter. However, the return per animal in summer exceeded its value in winter by LE 76 (Table 2). This result might be due to the reduced animal purchase prices in summer than that in winter being LE 1791 vs. LE 1982. This price difference could occur because small holders kept their calves to suck their dams in winter (berseem season), which decrease the supply of calves in winter. While in the beginning of the summer the small holder try to make early weaning and sell calves soon before the end of green fodder season. This increases the supply of calves which affected the animal purchase prices in the summer season.

Table 2. Economic analysis of fatting bullocks in the two studied different seasons

\begin{tabular}{lllllll}
\hline \multirow{2}{*}{ Items } & \multicolumn{7}{l}{ Summer season } & \multicolumn{2}{l}{ Winter season } \\
& \multicolumn{7}{l}{ LE } & $\%$ & LE & $\%$ & LE & $\%$ \\
\cline { 2 - 7 } & 53 & & 201 & & 254 & \\
Number of animals (head) & 34488 & 86 & 125433 & 87 & 159921 & 87 \\
Feeding cost & 2072 & 5 & 7505 & 5 & 9577 & 5 \\
Labor cost & 1530 & 4 & 5010 & 4 & 6540 & 4 \\
Veterinary services & 1241 & 3 & 4108 & 3 & 5349 & 3 \\
Administration & 1000 & 2 & 2000 & 1 & 3000 & 1 \\
Miscellaneous & 40331 & 100 & 144056 & 100 & 184387 & 100 \\
Total running costs & 94919 & & 398336 & & 493255 & \\
Total animal purchase price & 135250 & & 542392 & & 677642 & \\
Total variable costs & 156048 & & 605812 & & 761860 & \\
Total gross output & 20798 & & 63420 & & 84218 & \\
Gross margin* & 392 & & 316 & & 332 & \\
Return/animal & & & & & & 12 \\
Return/LE & & & & &
\end{tabular}


* Calculated according to Groen, 1989.

The return per LE per year represented in table 2 was estimated as $12 \%$. This value was slightly greater than that of the alternative chance of money by $2 \%$ only, indicating that, the investment in this type of projects is good but is not enough rewording. Also, it was less than that reported by Abdel-Aziz (1997) (24\%). This could be due to the high values of running cost. The items of running cost contributed $28 \%$ of total variable cost while the purchase of animal contributed $72 \%$ of the total variable cost. The value of purchase of animals was higher than that obtained by Osman (1997) (60\% of the total variable cost). Also, the price of a ready-made concentrate max was LE 570/ ton, whereas, this cost would be reduced to LE 470/ ton if the concentrates were formulated on farm from available local ingredients according to Osman (1997) which could add extra return of LE 68 per head.

The suggested alternative feeding regime reduced the feeding cost per animal from LE 624 in winter season to LE 429 which reduced the total feeding cost in winter from LE 125433 to LE 86234 (LE 62717 as concentrates and roughage plus LE 23517 as berseem). In this case, the contribution of feeding cost could be reduced from $87 \%$ to $82 \%$ of total running cost, while this value was still grater than the value of $77 \%$ which was reported by El-Ashery, et. al. (1985). This result could be due to the lower percentages of the other items of the running costs especially the percentage of labor cost $(5 \%)$ than that (11\%) which reported by El-Ashry, et. al. (1985). Also, this feeding regime was improved the return per LE per year from $12 \%$ to $19 \%$. This value was still less than that reported by Abdel-Aziz (1997) (24\%), because the items of total costs were more than the prices of sell fatting bullocks, which occurred due to the different ways of calculating cost items. The percentage of Abdel-Aziz (1997) $(24 \%)$ was an average value of the whole commercial feedlot farming system in Egypt.

It could be concluded that, the economic analysis showed that the intensification to obtain high biological performance in feedlot farms was not enough to obtain the high value of the return per LE per year. So, to improve the value of the return per LE per year, another alternative could be taken into consideration such as reducing the total feeding cost through using a different feeding regime such as using available green fodder.

\section{REFERENCES}

Abdel-Aziz, A. S., 1997. Recent developments in the livestock sector in Egypt. A report submitted to AGA, FAO, Rome., pp 53.

Asker A. A. and M. T. Ragab. 1959. Fattening Egyptian steers in Tahreer province. Alex. J. Agric. Res. 7: 157.

Crampton, E. W. and L. E. Harris, 1996. Applied Animal Nutrition, The Use of Feed Stuffs in The Formulation of Livestock Rations. Reprinted by S. Chand \& Company LTD, Ram Nagar, New Delhi, India by arrangement with M/s W. H. Freeman and Company USA.

Duncan, D. B., 1955. Multiple range and multiple F - test, Biometrics, 11: pp 42.

El-Ashry, M. A., H. M. Khattab, E. E. Ragheb and A. A. Ashmawy, 1985. Effect of nutritional treatments on the productive performance of Brown Swiss male caves. Egypt J. Anim. Prod. 25: 125. 
Galal, E., A. A. Younis, K. G. Attia and A. B. Awad. 1973. The performance of Egyptian native bullocks during fattening, Egypt. J. Anim. Prod. 2:71.

Groen, A. F., 1989. Economic values in cattle breeding. I. Influences of production circumstances in situations without output limitations. J. of Livestock Sci. 22:1.

Kamar, G. A. R., A. L. Badreldin and H. Z. Abd El- Hady, 1961. Factors affecting gain in fattening Egyptian steers on clover. J. Anim. Prod. U. A. R., 19: 32.

Osman, S. Hoda, 1997. Some economical and physiological studies on Egyptian buffaloes. Ph.D. Thesis, Univ. of Ain Shams, pp 180.

SAS, 1998. Statistical analysis system, STAT/ user's guide, release 603 ed. SAS Institute, Cary NC. U. S. A.

Sere, C. and H. Steinfels, 1996. World livestock production system, current status, issues and trends. FAO Animal Production and Health paper No. 127, Rome.

Younis, A. A. and M. M. Mokhtar, 1999. Impact of drought on livestock production in the North Western Coastal area of Egypt, A case study. In Workshop on Livestock and Drought: Policies For Cooping With Changes, Cairo: May 24-27, 1999. 133-140. 
التقييم الفنى والإقتصادي لتسمين العجول البقرى المصرية الأصيلة فى منطقة حديثة الاستصلاح

سمير محمد الثيخ، أحمد عبد المقصود يونس، مرفت محمود مختار مركز بحوث الصحراء ، المطرية ، القاهزة ، جمهورية مصر العريبية

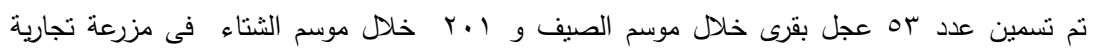

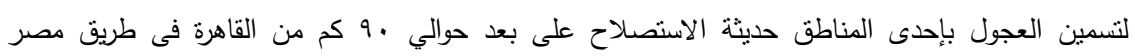

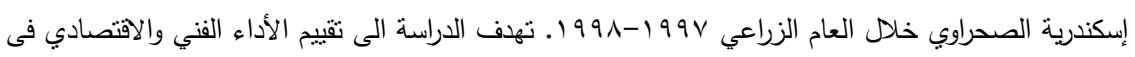

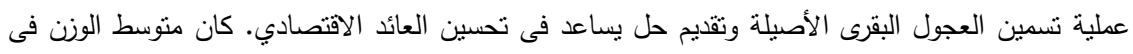

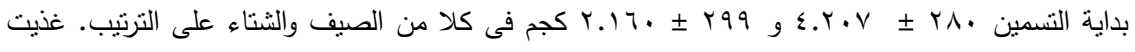

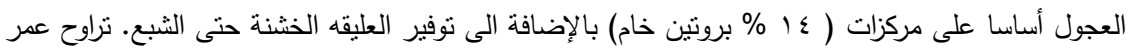

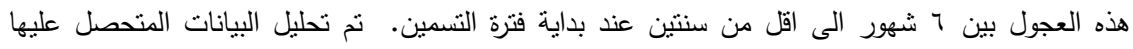

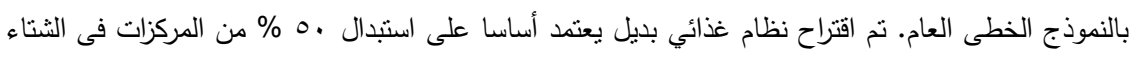

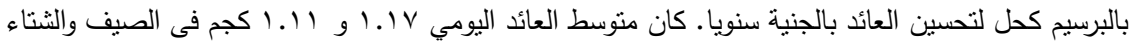

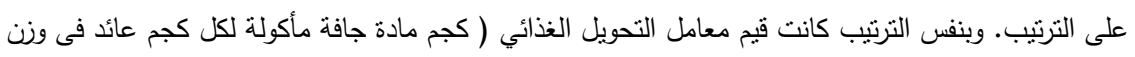

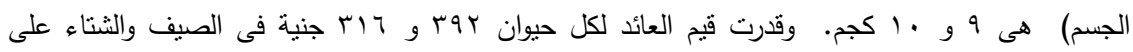

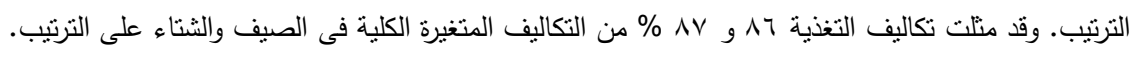

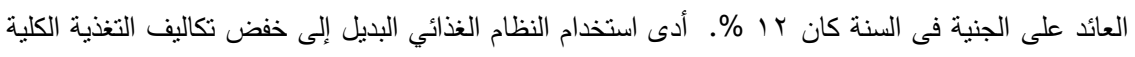

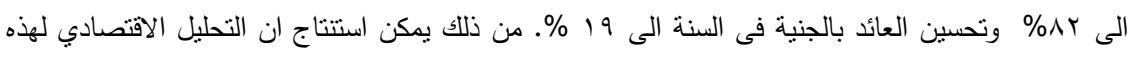

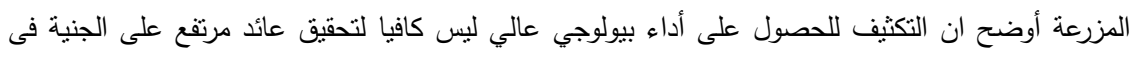
السنة. لذلك، لتحسين العائد، يجب ان توضع معايير أخرى فى الحسبان متل تقليل تكاليف التخذية باستخدام

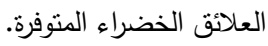

